2. Trân Phải Phụng và Đổng Khắc Thẩm (2013). Cảm nhận của người trong và ngoài ngành răng hàm măt về môtt số đăc điểm thẩm mỹ nu cười: đường giữa hàm trên, độ nghiêng mặt phẳng nhai và đướng cười. Tap Chí Học Viêt Nam, 411, 58-67.

3. Zhang Y., Xiao L., Li J. và cộng sự. (2010) Young People's Esthetic Perception of Dental Midline Deviation. Angle Orthod, 80(3), 515-520.

4. Pinho S., Ciriaco C., Faber J. và cộng sự (2007). Impact of dental asymmetries on the perception of smile esthetics. Am J Orthod Dentofacial Orthop, 132(6), 748-753.
5. A.J. Ker, Richard Chan, và Henry W. Fields (2008). Esthetics and smile characteristics from the layperson's perspective A computer-based survey study. Am J Orthod, 139, 1318-1327.

6. Tarulatha R. Shyagali, B. Chandralekha, và Deepak P. Bhayya (2008). Are ratings of dentofacial attractiveness influenced by dentofacial midline discrepancies?. Aust Orthod J, 24(2), 91-95.

7. McLeod C., Fields H.W., Hechter F. và cộng sư. (2011). Esthetics and smile characteristics evaluated by laypersons: A comparison of Canadian and US data. Angle Orthod, 81(2), 198-205.

\title{
NHỮNG VẤN ĐỀ CẦN LƯU Ý TRONG CHĂM SÓC BÊNH NHÂN SAU PHẪU THUÂT CHỈNH HÌNH XƯƠ'NG HAI HÀM TẠI KHOA RĂNG HÀM MẶT BỆNH VIỆN ĐẠI HỌC Y HÀ NộI: BÁO CÁO CHÙM CA BỆNH
}

Phùng Thị Huyền' ${ }^{1}$, Hoàng Thị Thảo¹, Nông Thị Phương Thảo, Phạm Quang Dương ${ }^{2}$, Nguyễn Trường Minh ${ }^{1,3}$

\section{TÓM TẮT}

Chăm sóc bệnh nhân sau phẫu thuật chỉnh hình xương hai hàm rất quan trong trong đảm bảo kết quả phẫu thuật. Việc nắm chắc kiến thức và kỹ năng đưa ra kế hoach chăm sóc toàn diên với muc tiêu điều trị bệnh nhần với kết quả tốt nhất là điều cần thiết. Chúng tôi trình bày kế hoạch chăm sóc và kết quả chăm sóc của một số trường hợp lâm sàng sau phâu thuât chỉnh hình xương và điểm qua về các chú ý trong chăm sóc về dinh dưỡng và vệ sinh răng miệng

Tư khóa: Chăm sóc sau phẫu thuật, phẫu thuật chỉnh hình xương

\section{SUMMARY}

\section{CLINICAL NOTES FOR POST OPERATIVE CARE IN BIMAXILLARY ORTHOGNATHIC SURGERY PATIENT AT ODONTO- STOMATOLOGY DEPARTMENT, HANOI MEDICAL UNIVERSITY HOSPITAL 2020}

Postoperative patient management is critical for high quality patient treatment and predictable patient outcomes in orthognathic surgery. In order to provide consistent, high quality outcomes for patients a thorough understanding and ability to implement postoperative management protocols and strategies must be gained. In this article, several bimaxillary orthognathic surgery cases are presentend with some clinical notes in nutritional and oral hygiene care.

Keywords: Postoperative care, orthognathic surgery

${ }^{1}$ Bênh viên Đai hơ Y Hà Nôi

${ }^{2}$ Bệnh viện Răng-Hàm-Mặt Trung ương Hà Nội

3 Viên Đào tạo Răng-Hàm-Mặt, Đại hoc Y Hà Nội

Chịu trách nhiệm chính: Nguyễn Trường Minh

Email: nguyentruongminh@hmu.edu.vn

Ngày nhận bài: 17.11.2020

Ngày phản biên khoa hoc: 23.12.2020

Ngày duyệt bài: 4.01.2021

\section{TỔNG QUAN}

Phẫu thuật chỉnh hình xương (Orthognathic surgery) là phẫu thuật chỉnh sửa các bất thường về xương của xương hàm trên, xương hàm dưới hoăc cả hai xương với mục tiêu sửa chữa các biến dạng của xương nhằm cải thiên thẩm mỹ và chức năng của bệnh nhân. ${ }^{1}$ Phấu thuật chỉnh hình xương gồm có phẫu thuật cắt xương hàm trên theo đường LeFort I, phẫu thuật chẻ dọc cành lên xương hàm dưới (BSSO) và phẫu thuật tạo hình cằm (Genioplasty) (hình 1-0).

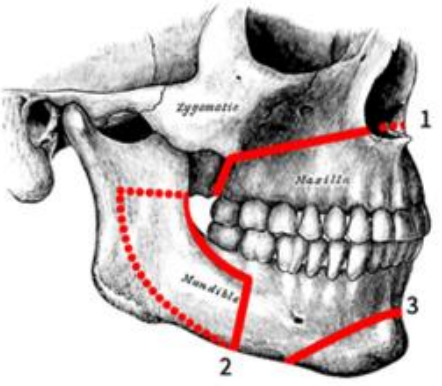

Hinh 1-0

Bệnh nhân phẫu thuật chỉnh hình xương thường nằm viện trong thời gian ngắn từ 5 đến 7 ngày. ${ }^{2}$ Kế hoạch chăm sóc không chỉ chăm sóc các nhu cầu của người bệnh trong giai đoạn tiền phẫu mà còn điều chỉnh kế hoạch đề phòng nếu hậu phẫu kéo dài. Sắp xếp kế hoạch chăm sóc và giáo dục sức khỏe phù hợp với từng giai đoạn trong phấu thuật chỉnh hình xương sẽ đóng góp tích cực vào mức đô tự chăm sóc của người bệnh cũng như sự hỗ trợ chăm sóc của người nhà người bệnh. 


\section{MộT SỐ CA BỆNH PHẪU THUẬT CHİNH HìNH XƯƠNG HÀM \\ Ca lâm sàng 1: Bệnh nhân nam 27 tuổi đi} khám do lệch mặt nặng. Chẩn đoán $U$ lồi cầu xương hàm dưới trái và lệch mă̆t. Bệnh nhân được chỉ định phẫu thuật chỉnh hình xương hai hàm kết hợp cắt u lồi cầu theo đường nội soi đưa khớp cắn về vị trí giải phẫu và chức năng. Sau mổ bệnh nhân được đánh giá mất 1 lít máu, được chỉ định truyền 2 đơn vị hồng cầu khối. Xét nghiệm sau mổ hồng câu 3,97 T/L. Hemoglobin $115 \mathrm{~g} / \mathrm{L}$, hematocrit 0,35 . Không mất thăng bằng điện giải. Sau mổ bệnh nhân được chuyển về khoa điều trị nội trú trong tình trạng bệnh nhân tỉnh, tiếp xúc được, niêm mac nhợt ít, da xanh, đầu chi ấm. Hàng ngày điều dưỡng theo dõi không thấy có chảy máu trong miệng qua đường mổ, vết mổ có sưng nề. Mạch 80 huyết áp 113/60 SpO2 100\%. Dẫn lưu trong miệng trong ngày đầu thêm $50 \mathrm{ml}$ dịch, dịch hồng lỏng. Xét nghiêm ngày thứ nhất sau mổ hồng cầu $3,94 \mathrm{~T} / \mathrm{L}$; huyết sắc tố $111 \mathrm{~g} / \mathrm{L}$; Hematocrit 0,34 . Không mất thăng bằng điện giải. Ngày thứ hai sau mổ bênh nhân tỉnh, hợp tác tốt, tìm đều mạch 79 huyết áp 110/60 spO2 100\%. Vết mổ còn sưng nề, dẫn lưu ra $10 \mathrm{ml}$ dịch lỏng hồng. Xét nghiệm 3,34T/L; Hemoglobin $111 \mathrm{~g} / \mathrm{L}$, Hematocrit (HCT). Da niêm mạc hồng, đầu chi ấm. Vết mổ trong miệng không chảy máu, dẫn lưu ra ít dịch lỏng hồng. Bệnh nhân được rút dẫn lưu. Sau 5 ngày nằm viện bệnh nhân ăn uống được, mặt còn sưng nề nhưng đã cả thiện hơn nhiều so với trước phẫu thuật, được ra viện. (hình 1-1).
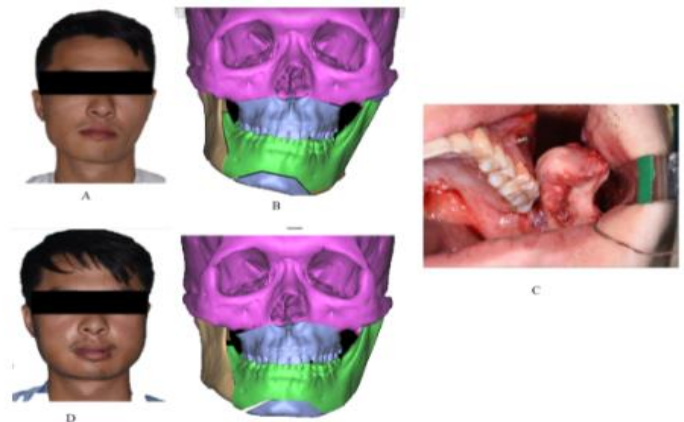

Hinh 1-1

A. Ảnh mặt bệnh nhân trước mổ B. Ảnh dựng hình dựa trên phim cắt lớp vi tính trước mổ và kế hoạch phẫu thuâtt của bệnh nhân. C. Ảnh khối u lồi cầu khi phẫu thuât. D. Ảnh măt bênh nhân sau phẫu thuật 5 ngày. E. Ảnh dựng hình dựa trên phim cắt lớp vi tính sau mổ 5 ngày (Ảnh của bác sĩ Nguyễn Trường Minh - khoa Răng Hàm Mặt, bệnh viện Đại học Y Hà Nội)
Ca lâm sàng 2: Bệnh nhân nữ 18 tuổi đi khám do vẩu hàm dưới, tiền sử khe hở môi vòm miệng đã phẫu thuật 4 lần. Bệnh nhân không có dị tật bẩm sinh ở cơ quan nào khác. Cân nặng $42 \mathrm{~kg}$ chiều cao $155 \mathrm{~cm}$. BMI 16,6. Thể trạng gầy. Bệnh nhân được chẩn đoán dị dạng xưởng hai hàm khớp cắn loại III, được chỉ định phẫu thuật chỉnh hình xương hai hàm. Sau mổ bệnh nhân được chuyền về khoa điều trị nội trú còn phù nề nhiều vùng miệng, hàm mặt, da xanh, niêm mạc nhợt, dẫn lưu ra ít dịch hồng. Há miệng hạn chể, uống được ít sữa, cân nặng 40 $\mathrm{kg}$. Bệnh nhân được mời hổi chẩn dinh dưỡng, được bác sĩ chẩn đoán dinh dưỡng: suy dinh dưỡng vừa/ bệnh nhân khe hở môi đã phẫu thuật chỉnh hình xương hàm ngày thứ 3 . Xác định nhu cầu năng lượng $1200 \mathrm{Kcal} / \mathrm{ngày}$, Protein từ $50-60 \mathrm{~g}$, điều dưỡng nuôi dưỡng qua đường miệng bằng sữa và chế độ cháo xay 3 bữa một ngàybằng xy lanh $50 \mathrm{ml}$, cao đầu khi ăn kết hợp nuôi dưỡng tĩnh mạch bằng glucose $10 \%$ và Aminoplasma $5 \%$ trong vòng 3 ngày đầu sau mổ (hình 1-3).

Trong thời gian đầu mới phẫu thuật cho người bệnh ăn chế độ ăn mềm, loãngnhư' cháo súp, sữa nhằm tránh xương hàm phải hoạt động nhiều làm ảnh hưởng đến vết mổ, chia nhiều bữa nhỏ bơm qua xilanh bằng đường miệng (Hình 1.4)

Sau mổ 5 ngày bệnh nhân cân nặng $41 \mathrm{~kg}$, da niêm mạc hồng, tự ăn cháo nhuyễn qua xy lanh 3 bữa/ngày. Bệnh nhân được ra viện sau 7 ngày.
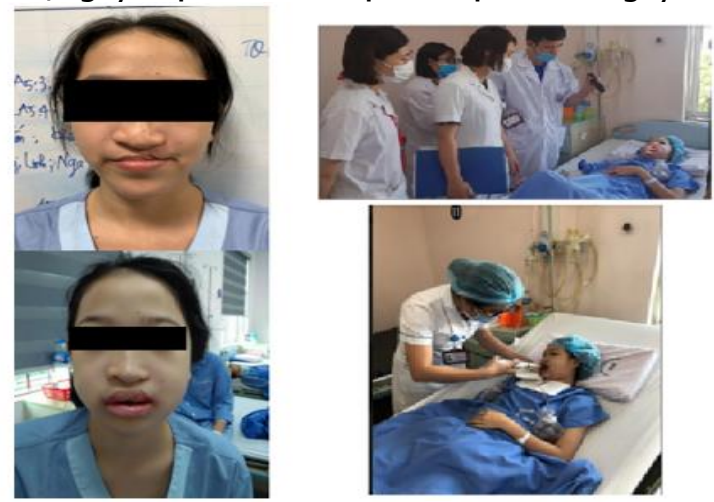

Hình 1-4: Hội chẩn dinh dưỡng và cho ăn qua đường miệng bằng xy lanh (phải)

Ca lâm sàng 3: Bệnh nhân nam 18 tuổi đi khám do vẩu hàm dưới, đang đeo mắc cài chỉnh nha. Tiền sử khỏe mạnh không có bệnh lý. Chẩn đoán di dạng xương hai hàm/ khớp cắn loại III. Bệnh nhân được chỉ định phấu thuật chỉnh hình xương hai hàm. Trước và trong mổ bệnh nhân được sử dụng kháng sinh Cefuroxim (Zinacef) 
750 mg x 2 lọ. Sau mổ ngày thứ nhất bệnh nhân tỉnh, tiếp xúc tốt, nhiệt độ 36,5 độ C. Xét nghiệm máu sau mổ ngày thứ nhất bạch câu $15,63 \mathrm{G} / \mathrm{L}$. Bệnh nhân vẫn tiếp tục được sử dụng kháng sinh Cefuroxim (Zinacef) 750 mg ngày 4 lọ chia 2 lần kết hợp Metronidazol (Metronidazol Kabi) 500 mg ngày 2 chai chia 2 lần. Vết mổ bám nhiều thức ăn do bênh nhân còn đeo mắc cài nhỉnh nha, không chảy máu chảy mủ, môi khô, lưỡi bẩn, tình trạng vệ sinh răng miệng kém. Điều dưỡng bơm rửa miệng vùng phẫu thuật bằng nước muối pha với betadine 3 lần một ngày (Hình 1-4).

Sau mổ ngày thứ hai bệnh nhân tỉnh, tiếp xúc tốt, nhiệt độ 37,4 độ $C$. Vết mổ còn sưng nề, đọng ít thức ăn, không chảy máu chảy mủ, răng và các khí cụ trong miệng ít mắc thức ăn. Xét nghiệm máu bạch cầu 11,19G/L. Bệnh nhân vẫn được sử dụng kháng sinh qua đường toàn thân kết hợp bớm rửa vệ sinh răng miệng tại chỗ 3 lần/ ngày bằng nước muổi pha betadine kết hợp máy tăm nước Waterpik và Chlorhexidine (HMU Chlorhexidine). Sau mổ ngày thứ năm, bệnh nhân tỉnh, tiếp xúc tốt, nhiệt độ 36,5 độ $C$. Vết mổ sạch, không đọng thức ăn, không chảy máu chảy mủ, các khí cụ ít mắc thức ăn. Xét nghiệm máu bạch cầu $6,36 \mathrm{G} / \mathrm{L}$. Bệnh nhân ngừng sử dụng kháng sinh đường toàn thân, điêu dưỡng duy trì bơm rửa vệ sinh răng miệng tại chố 3 lần/ngày.

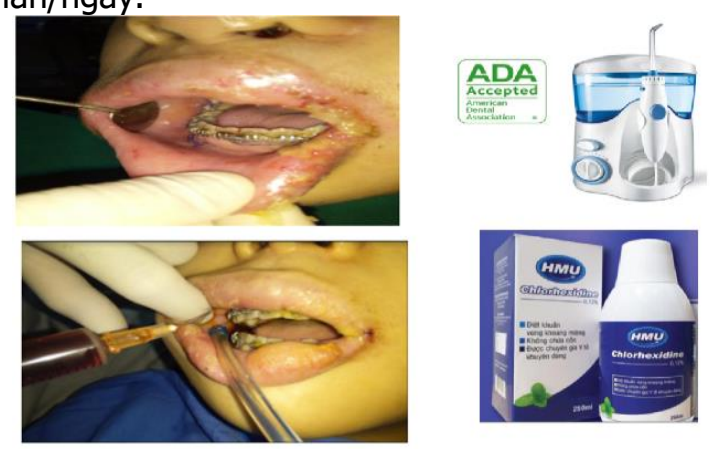

Hình 1.6. Đánh giá tình trạng vệ sinh răng miệng sau phấu thuật và vệ sinh răng miệng cho bệnh nhân bằng bởm rửa nước muối betadine

\section{BÀN LUÂ̂N}

Chăm sóc hậu phẫu cho người bệnh phẫu thuật chỉnh hình xương hết sức quan trọng và cần thiết, người bệnh được chăm sóc, theo dõi ở nhiều cấp độ khác nhau tùy theo từng giai đoạn và diễn biến của người bệnh do đó điều dưỡng phải theo dõi sát để có kế hoạch chăm sóc phù hợp. Hiệp hội hồi sức tích cực khuyến nghị phân loại mức chăm sóc cần thiết cho bệnh nhân như sau $^{3}$ :
- Mức 0: Bệnh nhân chăm sóc tại buồng điều trị (dịch truyền tĩnh mạch, quan sát 4 giờ một lần).

- Mức 1: Bệnh nhân cần theo dõi/ can thiệp thêm (truyền tînh mạch nhanh nhưng không cần theo dõi áp lực tĩnh mach trung tâm, bệnh nhân có mở khí quản hoặc hỗ trợ thận gián đoạn). Các bệnh nhân này có nguy cơ tiển triển xẩu và có thể cần nâng mức lên mức 2.

- Mức 2: Các bệnh nhân cần hỗ trợ một hệ cơ quan hoặc sau khi ở mức 3 nhưng tiến triển tốt lển.

- Mức 3: Các bệnh nhân cân hỗ trợ hộ hấp hoặc hỗ trợ nhiều hơn một hệ cơ guan.

Phần lớn các bệnh nhân phâuu thuật chỉnh hình xương hàm trẻ tuổi và ít có bệnh lý đi kèm do đó mức chăm sóc cần thiết thường ở mức 01. Tuy nhiên, phẫu thuâat viên cần phát hiện các bệnh nhân có thay đổi sinh lý bất thường và nầng mức chăm sóc tới mức cần thiết.

Sử dụng kế hoạch chăm sóc đã được làm sẵn để giúp cho việc truyền tải thông tin giữa các khoa dễ dàng, giảm thiểu tối đa lỗi trong giao tiếp ${ }^{4}$. Các hướng dẫn tại chỗ cần được tuân thủ nhằm điều trị cụ thể và các thuốc cần sử dụng ${ }^{5}$. Bao gồm kiểm soát đau, chống đông máu nội mạch, sử dụng corticosteroid, kháng sinh dự phòng, thuốc đường huyết, thuốc dự phòng chống nôn và buồn nôn và vệ sinh răng miệng... Môi trường phẫu thuât chỉnh hình xương sẽ tao ra vết thương bẩn-sạch. Các vi khuẩn nhiễm trùng thường nằm ở hệ sinh thái thông thường của khoang miệng và các xoang cạnh mũi. Nhiễm khuẩn của vết thương trong miệng thường do vi khuẩn kị khí như tụ cầu gram dương, trực khuẩn gram âm và song tụ cầu. ${ }^{5}$ Do đó, để đè phòng nhiễm khuẩn sau mổ ngoài việc sử dụng kháng sinh thì vệ sinh răng miệng đóng vai trò rất quan trọng. Hàng ngày người bệnh được bơm rửa, vệ sinh răng miệng bằng các dung dịch sát khuẩn và xúc miệng bằng nước xúc miệng chuyên dụng 2-3 lần/ ngày để đảm bảo răng miệng luôn sạch sẽ giúp vết mổ nhanh liền. Bên canhh đó, việc điều trị bằng glucocorticoid trước phẫu thuật đã được chứng minh có hiệu quả trong việc giảm sưng hậu phẩu ở phẫu thuật chỉnh hình xương. ${ }^{6}$ Tuy nhiên, liều và thời gian sử dụng vẫn còn chưa rõ ràng và giá trị của thuốc sau phẫu thuật vẫn còn chưa chắc chẳn ${ }^{6}$.

Từ lâu trong ngoại khoa đã có rất nhiều bằng chứng chứng minh việ̂c không đảm bảo dinh dưỡng trước mổ sẽ dẩn tới kết quả kém hơn, bao gồm cả nguy cơ nhiễm trùng và kéo dài thời gian điều trị nội trú. ${ }^{7}$ Tuy nhiên, so với phẫu thuật chỉnh hình xương, dinh dưỡng trước mổ ít khi được chỉ định. Nguyên nhân được cho là do 
đô tuổi của bênh nhân chỉnh hình xương (trẻ tuổi, ít có bệnh lý đi kèm) và loại phẫu thuật được chỉ định. Các nghiên cứu cho thấy bệnh nhẩn phẫu thuật chỉnh hình xương có thể giảm 3-7kg trong 6 tuần đầu sau phẫu thuật do không đạt được đủ chất dinh dưỡng cần thiết. ${ }^{1}$

Bệnh nhân nên có chế độ ăn mềm trong 6 tuần, bắt đầu bằng ăn lỏng trong 3-4 ngày đầu tiên bởi vì trong phẫu thuất chỉnh hình xương, dụng cụ kết hợp xương không cho phép bệnh nhân có thể ăn uống hoàn toàn như bình thường ngay. Chế độ ăn cần nhiêu năng lượng và protein. Đáp ứng với chế độ ăn để đảm bảo nuôi dưỡng về cả dinh dưỡng và nước rất quan trọng nhằm cải thiện lành thương và giảm thiểu biến chứng chỉnh hình xương. Tình trạng tâm lý của bệnh nhân mặc dù ít khi được bàn luận nhưng là một đặc điểm quan trọng trong chăm sóc toàn diện bệnh nhân. Các bằng chứng cho thấy chăm sóc dinh dưỡng đẩy đủ sẽ làm cải thiện tâm lý của bệnh nhân, tránh các tình trạng khó chịu hay trầm cảm. ${ }^{1}$ Các nghiên cứu cho thấy bệnh nhân phẫu thuật chỉnh hình xương có thể giảm $3-7 \mathrm{~kg}$ trong 6 tuần đầu sau phẫu thuâat do không đạt được đủ chất dinh dưỡng cần thiết. ${ }^{1}$ Tuy nhiên, tất cả người bệnh sau phẫu thuật chỉnh hình xương đều dược bác sĩ dinh dưỡng thăm khám, tư vấn và điều chỉnh chế độ ăn cho người bệnh đảm bảo calo và dinh dưỡng giúp người bệnh chóng hồi phục sức khỏe. Do đó, vai vai trò và sự tham gia của bác sĩ dinh dưỡng là cần thiết ở mỗi giai đoạn khác nhau, giảm thiểu biến chứng và nguy cơ sau mổ liên quan tới tình trạng dinh dưỡng kém.

Sau phẫu thuật chỉnh hình xương hàm việc duy trì vệ sinh răng miệng rất quan trọng để tránh các bệnh lý răng miêng như sâu răng hoăc bệnh nha chu. Bệnh nhân sau phẫu thuật có nguy cơ cao do vừa đeo khí cụ chỉnh nha, hay hạn chế há miệng và đau sau phẫu thuât. Bàn chải kẽ răng thường có ích khi sử dung cùng bàn chải thường với lợi thế lấy được mảng bám dưới Iợi với độ sâu $2-2.5 \mathrm{~mm} .{ }^{8}$ Các bàn chải này rất có ích khi làm sạch vòng quanh các khí cụ cố định ở bệnh nhân chỉnh hình xương. Bàn chải điện ngày càng trở nên phổ biến và chiếm thị phần đáng kể trên thị trường vệ sinh răng miệng. Một nghiên cứu so sánh bàn chải điê̂n và bàn chải thường cho thấy bàn chải điện với lực xoay lấy bỏ được mảng bám và làm giảm viêm Iợi hiệu quả hớn bàn chải tay ${ }^{8}$. Bàn chải máy được thiết kế đặc biệt sử dụng cho bệnh nhân có khí cư chỉnh nha cỗ đinh đã có mặt trên thi trường và có ích với bệnh nhân chỉnh nha. Có rất nhiều sản phẩm hóa học được sử dụng để ức chễ hình thành mảng bám vi khuẩn. Chlorhexidine với tác dụng chống vi khuẩn gram âm, gram dương cũng như bào tử nên là một trong những sản phẩm hiêu quả nhất.Viêc bám dính trên cả mô mềm và mô cứng giúp cho chlorhexidine luôn giữ được nồng độ hiệu quả trong thời gian dài. Tuy nhiên khi sử dụng trong môt thời gian dài chlorhexidine có thể làm thay đổi vị giác, đổi màu răng/ mắc cài cũng như sưng tuyến mang tai. Thường bệnh nhân được khuyến cáo súc miệng 2 lần một ngày trong 7 ngày đầu sau phẫu thuật.

\section{KẾT LUÂ̂N}

Chăm sóc hậu phẫu tốt ở bệnh nhân phẫu thuật chỉnh hình xương bắt đầu từ ngay lúc bênh nhân ra khỏi phòng phẫu thuât cho tới khi ra viện giúp cho việc đảm bảo kết quả phẫu thuật.

Đánh giá và tái đánh giá thường xuyên giúp cho việc phẫu thuật an toàn. Phẫu thuật chỉnh hình xương sẽ làm thay đổi sinh lý dẫn tới thay đổi tình trạng dinh dưỡng và cần được chăm sóc dinh dưỡng cũng như chăm sóc răng miệng kỹ lưỡng trong suốt quá trình nằm viện.

\section{TÀI LIÊU THAM KHẢO}

1. Robinson RC, Holm RL. Orthognathic surgery for patients with maxillofacial deformities. AORN J. 2010;92(1):28-49; quiz 50-22.

2. Sexton J. Orthognathic surgery in a surgical day care setting. Journal of oral and maxillofacial surgery: official journal of the American Association of Oral and Maxillofacial Surgeons. 1991; 49 (8):917.

3. The Intensive Care Society Standards. Levels of Critical Care for Adult Patients. 2009.

4. Karakaya A, Moerman AT, Peperstraete $H_{\text {, }}$ Francois K, Wouters PF, de Hert SG. Implementation of a structured information transfer checklist improves postoperative data transfer after congenital cardiac surgery. European journal of anaesthesiology. 2013;30(12):764-769.

5. Tan SK, Lo J, Zwahlen RA. Are postoperative intravenous antibiotics necessary after bimaxillary orthognathic surgery? A prospective, randomized, double-blind, placebo-controlled clinical trial. Int J Oral Maxillofac Surg. 2011;40(12):1363-1368.

6. Chegini S, Dhariwal DK. Review of evidence for the use of steroids in orthognathic surgery. The British journal of oral \& maxillofacial surgery. 2012;50(2):97-101.

7. Busby GP, Mullen JL, Mathews DC, Hobbs CL, osato EF. Prognostic nutritional index in gastrointestinal surgery. Am J Surg. 1980;139:160167.

8. Robinson PG, Deacon SA, Deery $C_{\text {, }}$ et al. Manual versus powered toothbrushing for oral health. Cochrane Database Syst Rev. 2005(2):CD002281. 